\title{
Laura Karttunen
}

\section{Sorron akselit ja sentimentaalisuuden anti. Feminististen ja queer-kertomusteorioiden symposiumi Columbuksessa 10-12.5.2011}

Susan Lanser käynnisti feministisen narratologian vuonna 1986 artikkelillaan "Towards a Feminist Narratology”. Nyt, 25 vuotta myöhemmin, hän linjasi tutkimusalan tulevaisuutta The Ohio State Universityn järjestämässä feministisen ja queer-kertomusteorian symposiumissa. Paikalle oli saapunut kymmeniä alan kärkihahmoja esitelmöimään ja väittelemään sopuisassa ilmapiirissä.

Kun sana kertomusteoria on laajentunut käsittämään lähes kaikkea kertomuksia koskevaa kirjoittamista, Susan Lanser peräänkuulutti feminististä narratologiaa, joka ei ole naiivin sisältökeskeistä vaan keskittyy kertovaan muotoon. Hän myötäili Susan Sontagin näkemystä, ettei kirjallisuudentutkimuksen tehtävänä ole osoittaa, mitä tekstit merkitsevät vaan millaisia ne ovat. Yhtä lailla kuin sisällöt, muodotkin ovat yhteiskunnallisesti merkityksellisiä. Esimerkiksi romaanihenkilöissä sisältö ja muoto kietoutuvat yhteen.

Esiintyjistä ainoana Lanser tarkasteli tulevaisuuden haasteita myös narratologian eikä vain feminismin näkökulmasta. Hänen mukaansa feministisen kertomustutkimuksen kaanonia on laajennettava 1800- ja 1900-luvun vaihteen kanonisen naiskirjallisuuden ulkopuolelle ja muihinkin kuin kaunokirjallisiin teksteihin. Esimerkkinä terveestä kehityssuunnasta hän listasi lehdessä Nursing Philosophy ilmestyneitä kertomusaiheisia artikkeleita. Kun narratologian käsitteitä ja metodeja yritetään soveltaa muunlaisiin teksteihin, nähdään, mitkä niistä ovat laajasti käyttökelpoisia ja mitkä eivät. Lanser kärjisti, että narratologit puuhastelevat edelleen asioiden parissa, jotka eivät ole tärkeitä, kuten taksonomiat kreikansekaisine termeineen.

Symposiumin merkittävimpänä antina pidin Lanserin linjanvedon ohella Susan Fraimanin esitelmää, jossa hän arvosteli kriittistä eläintutkimusta ja sen keskeistä teoreetikkoa Cary Wolfea alan feministisen varhaishistorian unohtamisesta. Wolfen vuonna 2003 ilmestynyt teos Animal Rites näyttäytyy tämän trendialan lähtölaukauksena, vaikka ekofeministit olivat tutkineet samanlaisia kysymyksiä jo 40 vuotta aiemmin. Esimerkiksi Donna Haraway, josta sittemmin tuli feminismin suuri nimi, teoretisoi uransa alussa erityisesti eläimiin liittyviä kysymyksiä. Fraiman epäilee, että kriittinen eläintutkimus on halunnut ottaa etäisyyttä ekofeminismistä, koska tämä herättää epätoivottuja mielleyhtymiä sentimentaaliseen eläinrakkauteen ja muihin 
pehmeisiin naisarvoihin.

Fraimanin mukaan uusimuotoinen kriittinen eläintutkimus antaa kohtuuttoman suuren painoarvon Derridan kissakertomukselle L'animal que donc je suis (2006). Hän näkee sekä tutkimusalassa että Derridan tekstissä sukupuoleen liittyvää ahdistusta. Feminiiniseksi mielletyn kissan herkeämätön katse, joka suuntautuu alastoman filosofin "sukupuolisuuteen", saa tämän tuntemaan häpeää. Yhteys toisen eläinlajin edustajaan toteutuu katseen kautta, minkä Fraiman mieltää maskuliiniseksi piirteeksi. Sen sijaan eläintutkija Barbara Smutsin teoksessa Sex and Friendship in Baboons (1985) paviaani tunnustelee kirjailijan sormenkynsiä. Vaikka eläin myös katsoo tutkijaa silmiin, etusijalla on kosketus eikä visuaalisuus. Smutsin eläinkohtaamista luonnehtii hellyys, toisen huomioiminen ja ihmettely, kun taas Derrida ahdistuu eläimeen liittyvistä saalistamisen ja tappamisen mielleyhtymistä ja pyrkii säilyttämään asemansa alfaeläimenä. Fraiman laajensi tarkasteluaan myös lihan syömisen politiikkaan ja analysoi Harawayn ja Carol Adamsin tekstejä, joissa kuvataan arkista eläinrakkautta.

Monet symposiumin esitelmät käsittelivät tunteita: miten ja millaisia tunteita romaanit herättävät ja millaisia yhteiskunnallisia seurauksia esimerkiksi sentimentaalisuudella voi olla. Teoreettisen kehyksen pohdinnoille tarjosi filosofiassa ja humanistisissa tieteissä tapahtunut affektiivinen käänne. Tunteista puhuneet Suzanne Keen ja Kay Young pohtivat, ettei kertomusteoriassa pinnalla oleva kognitiivinen lähestymistapa vaikuta yhtä antoisalta feministiselle kirjallisuudentutkimukselle kuin edellisen tutkijasukupolven hyödyntämä psykoanalyyttinen kehys. Aivotutkimus ei myöskään tunnu tarjoavan riittäviä välineitä kirjallisuuden herättämien moniulotteisten tunteiden kuten empatian analysointiin.

Queer-tutkijoille kuten Ann Cvetkovichille ajankohtaisena projektina näyttäytyy arkistotyö, jossa yhdessä HLBT-ruohonjuuriliikkeiden ja -taiteilijoiden kanssa dokumentoidaan yhteistä tunnehistoriaa. Näin luodaan vasta-arkistoja ja tuodaan esille tunnehistorioita, jotka historiankirjoitus on painanut villaisella. Teoreettisena perustana projektille toimii Eve Kosofsky Sedgwickin korjaavan lukemisen käsite (reparative reading). Kriittistä teoriaa on Sedgwickin mukaan luonnehtinut yhä hienovaraisempien sorron muotojen etsiminen ja paljastaminen, kun taas korjaava lukeminen tai toiminta korostaa mielihyvää, lohtua ja toivoa. Korjaava arkistotyö voi olla esimerkiksi 70-luvun feministi- ja lesboliikkeiden t-paitojen keräämistä tai virallisten arkistojen läpikäyntiä sukupuoli- ja seksuaalivähemmistöjen näkökulmasta. Kiintoisan esimerkin queer-arkistosta ja sentimentaalisuuden positiivisista mahdollisuuksista esitteli Jesse Matz. Homonuorten itsemurhien herättämänä toimittaja-kirjailija Dan Savage alkoi kumppaninsa kanssa kerätä aikuisilta rohkaisevia todistajanlausuntoja (www.itgetsbetter.org). Koulukiusatuille vakuutetaan, että elämä paranee, kun high school on ohi. Matz kiinnitti huomion todistajanlausuntojen aikarakenteeseen. Yhtäältä 
nettivideoissa viitataan parempaan tulevaisuuteen. Toisaalta korostetaan sentimentaalisuutta hipovalla tavalla, että jo nyt on olemassa homoseksuaalien yhteisö, joka tarjoaa hyväksyntää.

Rebecca Wanzon esitelmässä affektit esiintyivät kielteisemmässä valossa. Hän kiinnitti huomiota Kathryn Stockettin romaanin Piiat (The Help) saamaan vastaanottoon. Amazonin verkkosivuille kirjoitetuissa arvioissa valkoiset lukijat palaavat nostalgisiin lapsuudenmuistoihinsa mustista lastenhoitajistaan, jotka huolehtivat heidän kaikista tarpeistaan. Romaani vaikutti tavoittavan jotakin olennaista valkoisten amerikkalaisten tunnehistoriasta. Wanzo näkee teoksen kuitenkin ongelmallisena, koska se ensinnäkin hyödyntää nostalgista mammy-hahmoa ja toiseksi näyttää, että valkoisen naisen täytyy opettaa mustia kapinoimaan, mutta lopulta unohtaa täysin, että lastenhoitajilla on omakin elämä valkoisen kodin rajojen ulkopuolella. Valkoisen lapsen rakkaus ei liene ollut mustan lastenhoitajan elämän tärkein asia, vaikka se romaanissa sellaisena esitetään.

Sentimentaalisuuden ohella symposiumin avainsanaksi muodostui intersektionaalisuus eli ajatus, että identiteetti muodostuu lukuisista osatekijöistä: sukupuoli, luokka, seksuaalinen suuntautuminen, kansallisuus, vammaisuus, uskonto jne. Sorretuiksi yhteiskunnassa tulevat erityisesti ne, jotka asemoituvat toisiksi usealla akselilla. Tilan ja monikansallisen kirjallisuuden teoreetikko Susan Stanford Friedman käsitteli uskontoa, joka on ollut yllättävän näkymättömissä feministisessä tutkimuksessa. Syy lienee se, että sukupuoli on väistämättä ihmisen identiteetin osatekijä, mutta uskonto on sellainen vain joillekin. Friedmanin mukaan uskonto ei ole rasismin tai heteronormatiivisuuden kaltainen sorron akseli, vaikka sen fundamentalistiset muodot perustuvatkin me ja muut -asetelmaan. Hän vertaili islamin, sukupuolen ja seksuaalisuuden kysymyksiä kahdessa kehityskertomuksessa, Leila Aboulelan romaanissa The Translator (2006), joka kuvaa sudanilaisen naisen avioliittoa skotlantilaisen miehen kanssa, ja Randa Jarrarin romaanissa A Map of Home (2008), jonka naispäähenkilön kapinallisuus ja biseksuaalisuus eivät estä muodostamasta henkilökohtaista suhdetta islamiin.

Kun konferenssit järjestetään luksushotellin ikkunattomassa kellarikerroksessa, itse maailma ei lähtökohtaisesti pääse sisään. Jos ikkunoita olisi ollut, olisin nähnyt kuinka viereisellä pääkadulla juostiin rintasyövän tutkimuksen hyväksi. Tien molemmin puolin oli pysäköity riviin kymmeniä Harley Davidson -moottoripyöriä, joita kuljettajat murisuttivat aina juoksijoiden lähestyessä. 